\title{
Photodegradation of Cinnamic Acid Solution in the Presence of Various Oxidizing Agents on $\mathrm{TiO}_{2}$ and Fe- $\mathrm{TiO}_{2}$ Catalysts
}

Ha Cam Anh ${ }^{1}$, Luu Cam Loc ${ }^{1,2 *}$, Nguyen $\operatorname{Tri}^{2}$, Nguyen Phung $\mathrm{Anh}^{2}$, Nguyen Thi Nga $\operatorname{Tot}^{1}$, Nguyen Thi Thuy $\mathrm{Van}^{2}$ and Hoang Tien Cuong ${ }^{2}$

1. University of Technology, Vietnam National University Ho Chi Minh City, 268 Ly Thuong Kiet Str., Ho Chi Minh City 70100, Vietnam

2. Institute of Chemical Technology, Vietnam Academy of Science and Technology, 01 Mac Dinh Chi Str., Ho Chi Minh City 70100, Vietnam

\begin{abstract}
In this paper, $\mathrm{TiO}_{2}$ and $\mathrm{Fe}$-doped $\mathrm{TiO}_{2}$ had been prepared by the sol-gel method. Physico-chemical characteristics of the catalysts were determined by the methods of BET Adsorption, XRD, FT-IR, and UV-Vis spectroscopies. Experimental results showed that the The modification of $\mathrm{TiO}_{2}$ catalyst with Fe led to reducing the crystallite size and PZC, and extending the spectrum of photon absorption to the visible region. The activity of obtained catalysts for photodegradation of cinnamic acid (CA) solution in the presence of various oxidizing agents $\left(\mathrm{O}_{2}, \mathrm{O}_{3}\right.$ and $\left.\mathrm{H}_{2} \mathrm{O}_{2}\right)$ was investigated and the optimum reaction conditions were identified. It follows that the addition of $\mathrm{Fe}$ additive is able to reduce the optimal catalyst concentration 3-5 times and increase the catalytic activity. It was found that $\mathrm{O}_{3}$ and $\mathrm{H}_{2} \mathrm{O}_{2}$ agents showed the higher efficiency for cinnamic acid photodecomposition than usual $\mathrm{O}_{2}$. In optimum conditions, after 90 minutes reaction, the conversion of cinnamic acid in the solution achieved $58.5,77.7$ and $83.1 \%$ on $\mathrm{TiO}_{2}$ and $85.7,82.8$ and $89.4 \%$ on $\mathrm{Fe}-\mathrm{TiO}_{2}$ in the presence of $\mathrm{O}_{2}, \mathrm{O}_{3}$ and $\mathrm{H}_{2} \mathrm{O}_{2}$ respectively.
\end{abstract}

Key words: Photodegradation, cinnamic acid, oxidizing agents, $\mathrm{TiO}_{2}$ and $\mathrm{Fe}-\mathrm{TiO}_{2}$.

\section{Introduction}

Photocatalysis is an advanced process having many useful applications, particularly in environment cleanup [1]. Intrinsically, photocatalysis is refers to the reaction accelerated by light in the presence of catalyst, normally a semiconductor. In fact, $\mathrm{TiO}_{2}$ is the best choice for commercial catalyst because of its high photocatalytic activity under UV irradiation, chemical and thermal stability, non-toxicity, reasonable band gap energy, easily available, and low cost. Up to now, compared to the other photocatalysts, $\mathrm{TiO}_{2}$ has better performance and is preferable.

$\mathrm{TiO}_{2}$ in anatase phase, whose energy exceeds the band gap of $3.2 \mathrm{eV}$, could be activated under

*Corresponding author: Luu Cam Loc, Dr., Sci., professor, research fields: petroleum chemistry, catalysis, nanomaterials, kinetics and mechanism of catalytic processes. ultraviolet light $(\lambda<387 \mathrm{~nm})$. However, it is broadly known that only 3-5\% of sunlight is UV-irradiation, capable to activate $\mathrm{TiO}_{2}$ becoming a photocatalyst. Therefore, widening the light absorbing zone of $\mathrm{TiO}_{2}$-based photocatalyst into visible range is really necessary. In addition, $\mathrm{e}^{-} / \mathrm{h}^{+}$recombination is a practical problem related to reduce quantum yield and need to be considered carefully. There are several ways to modify $\mathrm{TiO}_{2}$ including metal-ion implanted $\mathrm{TiO}_{2}$ (using transition metals: $\mathrm{Cu}, \mathrm{Co}, \mathrm{Cr}, \mathrm{Mo}, \mathrm{V}, \mathrm{W}$, $\mathrm{Fe}, \mathrm{Ag}, \mathrm{Au}$ and $\mathrm{Pt}$ ), composite $\mathrm{TiO}_{2}$ with carbon nanotubes, dye sensitizers or other photo-sensitive semiconductors (e.g. $\mathrm{CdS}, \mathrm{ZnO}$ ), non-metal and metal doping [2]. As it follows from our previous investigation [3], Fe-doped $\mathrm{TiO}_{2}$ has been considered as an effective dopant for photoactivity enhancement. Photocatalysts of pure and Fe-modified $\mathrm{TiO}_{2}$ with a 
particle size of about 20-30 nm were prepared by the sol-gel method. Doping $\mathrm{TiO}_{2}$ by iron enabled red shift the photon absorbing zone of $\mathrm{TiO}_{2}$ (with $\lambda$ up to 464 $\mathrm{nm}$ ) and reduced the value of the band gap energy down to $2.67 \mathrm{eV}$ [3]. Fe-modified $\mathrm{TiO}_{2}$ catalysts showed advantages over the pure $\mathrm{TiO}_{2}$ sample when operating in the photooxidation of p-xylene in gas phase under visible light radiation. The utilization of UV and visible light in a combined mode of irradiation for the catalyst Fe-doped $\mathrm{TiO}_{2}$ increased its activity and degradation efficiency in the p-xylene photooxidation by up to two to three times with considerable stability [3].

The photodegradation of numerous organic compounds were investigated on $\mathrm{TiO}_{2}$, including pesticides and phenolic contaminants in wastewaters such as phosphamidon diphenamid [4-8], indole-3-acetic acid and indole-3-butyric acid [9], dimethoate [10], propham, propachlor and tebuthiuron [11], 4-chlorophenol and 2,6-dichlorophenol [12]); emerging contaminants in municipal wastewater (i.e. acetaminophen, antipyrine, atrazine, carbamazepine, diclofenac, flumequine, hydroxybiphenyl, ibuprofen, isoproturon, ketorolac, ofloxacin, progesterone, sulfamethoxazole and triclosan) [13, 14], dyes (reactive red 4, methylene blue [15-17], reactive red 222 [18], crystal violet [19], remazol black [16], methyl orange and congo red [20]), and herbicides (picloram [21] and imazethapyr [22]), etc.

Cinnamic acid $\left(\mathrm{C}_{9} \mathrm{H}_{8} \mathrm{O}_{2}\right)$ - an unsaturated carboxylic acid is one of the phenolic compounds commonly present in oil mill vegetation and washing wastewaters, where its concentration reaches up to $106 \mathrm{mg} / \mathrm{L}$ [23]. Many works have reported the degradation of this acid by several advanced oxidation processes (AOPs) including $\mathrm{H}_{2} \mathrm{O}_{2}$ [24], Fenton processes (i.e. $\mathrm{Cu}^{2+} / \mathrm{H}_{2} \mathrm{O}_{2}$ [24], $\mathrm{Fe}^{2+} / \mathrm{H}_{2} \mathrm{O}_{2}[24,25]$ or $\mathrm{Fe}^{2+} / \mathrm{H}_{2} \mathrm{O}_{2}$ under UV light [25]). However, much less is known about the treatment of cinnamic acid solutions by photocatalytic systems $\mathrm{TiO}_{2}-\mathrm{UV}$.

Therefore, the scope of this work is to investigate the effect of various oxidizing agents (i.e. $\mathrm{O}_{2}, \mathrm{O}_{3}$ and $\mathrm{H}_{2} \mathrm{O}_{2}$ ) on the removal efficiency of cinnamic acid (CA) in model effluents on $\mathrm{TiO}_{2}$ and $\mathrm{Fe}-\mathrm{TiO}_{2}$ photocatalysts.

\section{Materials}

\subsection{Preparation of Catalysts}

Pure $\mathrm{TiO}_{2}$ catalyst was prepared by the sol-gel method as follows: $15 \mathrm{~mL}$ of tetraisopropyl orthotitanate $\mathrm{Ti}\left(\mathrm{OC}_{3} \mathrm{H}_{7}\right)_{4}$ (TTIP) was added to an ethanol- $\mathrm{HNO}_{3}$ mixture with a $\mathrm{pH}$ of about 3-4 and stirred for 10 minutes to obtain a transparent solution. The solution was added drop wise to $10 \mathrm{~mL}$ of deionized water, stirred at room temperature for 2 hours to form a highly viscous solution. The solution was standing for 24 hours to obtain a transparent soft gel. The sample was dried in three stages at room temperature, $80{ }^{\circ} \mathrm{C}$ and $100{ }^{\circ} \mathrm{C}$ for 2 hours at every stage. Finally, the calcination and crystallization were carried out at $450{ }^{\circ} \mathrm{C}$ for 2 hours in an air flow and then the powder $\mathrm{TiO}_{2}$ was obtained and is denoted by $\mathrm{TiO}_{2}$.

$\mathrm{TiO}_{2}$ catalyst doped $0.1 \mathrm{~mol} \% \mathrm{Fe}_{2} \mathrm{O}_{3}$ was prepared by the sol-gel method according to above procedure, with a difference $10 \mathrm{~mL}$ of deionized water added drop wise was replaced by $10 \mathrm{~mL} \mathrm{Fe}\left(\mathrm{NO}_{3}\right)_{3}$ solution in deionic water. The powder Fe-doped $\mathrm{TiO}_{2}$ was obtained and denoted as $\mathrm{Fe}-\mathrm{TiO}_{2}$.

\subsection{Physico-Chemical Characteristics Analyses}

Physico-chemical characteristics of catalysts were investigated by various methods, including BET surface areas and pore volumes $\left(\mathrm{N}_{2}\right.$ physisorption), X-ray powder diffraction analysis (XRD), Raman spectroscopy, scanning electron microscopy (SEM), transmission electron microscopy (TEM), Fourier transform infrared (FT-IR), and UV-Vis absorption spectroscopy. The point of zero charge (PZC) of obtained catalysts was determined by acid-base titration method. 


\subsection{Photocatalytic Activity}

Experiments for photocatalytic degradation of cinnamic acid in the presence of various oxidizing agents $\left(\mathrm{O}_{2}, \mathrm{O}_{3}\right.$ and $\left.\mathrm{H}_{2} \mathrm{O}_{2}\right)$ were carried out using the batch photocatalytic system illustrated in Fig. 1. Photocatalytic reactor is the inner quartz double-wall jacket with inlet and outlet for the water circulation to maintain the temperature of the reaction mixture. Reactor is designed with the volume of reaction solution of $250 \mathrm{~mL}$ and radium ralutec $9 \mathrm{~W} / 78$ UVA G23 lamp (36 lamps, $\lambda \approx 350-400 \mathrm{~nm}$, Capacity each lamp $0.160 \mathrm{~mW}$ ). The photo-reactor was isolated by using a thick plastic black cover. In addition, the reaction mixture is mixed by magnetic stirrer.

In all experiments, reaction solution volume 250 $\mathrm{ml}$, cinnamic acid concentration $50 \mathrm{mg} / \mathrm{L}$ and stirring $250 \mathrm{rpm}$ were fixed. Influences of catalyst concentration and operation parameters (i.e. initial solution $\mathrm{pH}$, temperature of reaction solution and dissolved oxygen (DO) or flow rate of $\mathrm{O}_{3}$ supply or $\mathrm{H}_{2} \mathrm{O}_{2}$ concentration) on the photoactivity of catalysts were investigated. The catalysts were separated by filtration (syringe filter, pore size $0.22 \mu \mathrm{m}$, sarttorius NY) from the aqueous solutions prior to analyzing the samples. The concentrations of cinnamic acid (CA) in the solution were determined by UV-visible spectrophotometer (UV-1800, Shimadzu, Japan) at $\lambda_{\max }=272 \mathrm{~nm}$.

\section{Results and Discussion}

\subsection{Physico-Chemical Characteristics of Catalysts}

The XRD spectra as well as the Raman spectra of catalysts showed that $\mathrm{TiO}_{2}$ only existed in anatase phase. On XRD spectra of both catalysts (Fig. 2), characteristic peaks of $\mathrm{TiO}_{2}$ anatase phase appeared at $2 \theta=25.3^{\circ}, 37.8^{\circ} ; 48.1^{\circ} ; 55.1^{\circ}$ and $62.7^{\circ}$ with the strongest intensity at $2 \theta=25.3^{\circ}$. The characteristic peaks of rutile phase $\left(2 \theta=26.9^{\circ}, 35.7^{\circ}, 40.8^{\circ}, 53.7^{\circ}\right.$, $55.8^{\circ}$ and $63.5^{\circ}$ ) [26] almost did not appear. According to authors [27], $\mathrm{Fe}-\mathrm{TiO}_{2}$ catalyst only converted anatase to rutile phase when Fe concentration was more than $0.1 \mathrm{~mol} \%$. The intensity of the anatase peaks in $\mathrm{Fe}$-doped $\mathrm{TiO}_{2}$ is higher than that of pure $\mathrm{TiO}_{2}$ that indicated the crystallite of $\mathrm{Fe}$-doped $\mathrm{TiO}_{2}$ is better than $\mathrm{TiO}_{2}$ catalyst. The authors [28] also obtained the same results and proposed the incorporated $\mathrm{Fe}$ into $\mathrm{TiO}_{2}$ did not change the crystal structure of $\mathrm{TiO}_{2}$ due to probably $\mathrm{Ti}^{4+}$ ions in the crystal framework of $\mathrm{TiO}_{2}$ was replaced by $\mathrm{Fe}^{3+}$ ions.

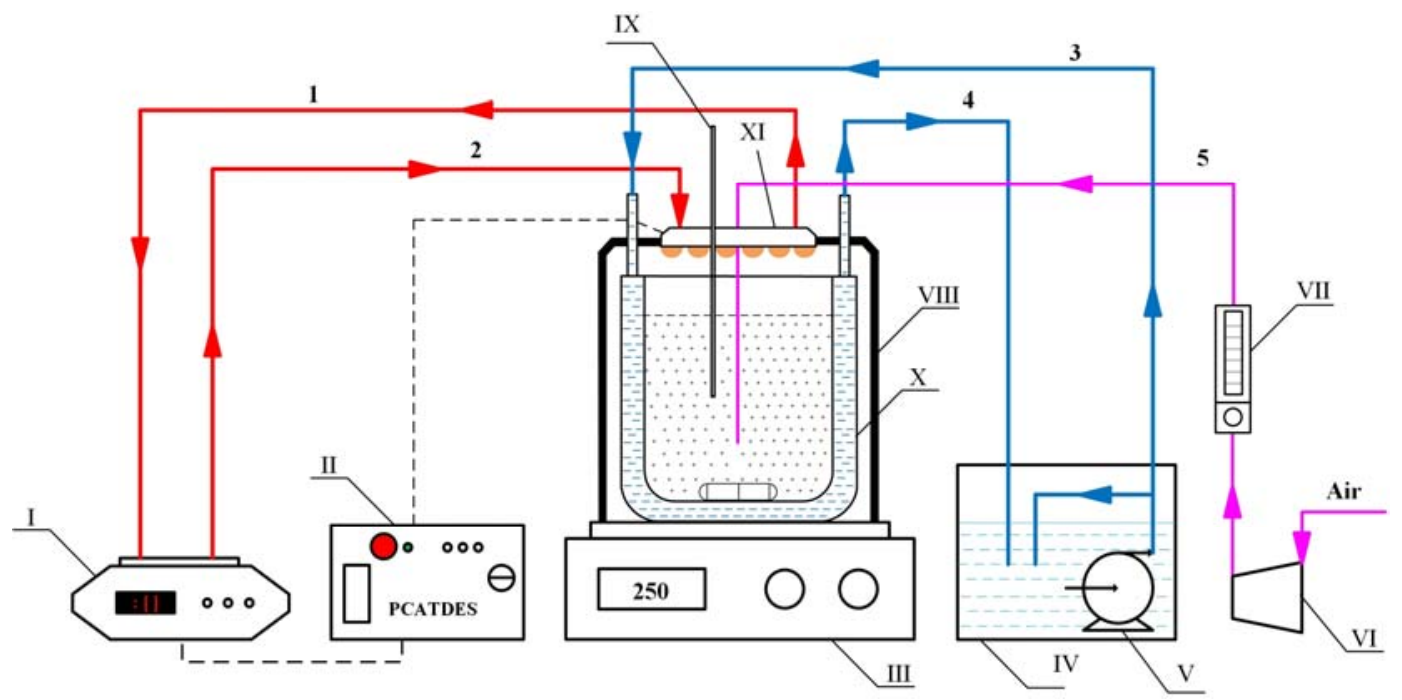

Fig. 1 Schematic diagram of photocatalytic reaction system.

I - Liquid cooling system; II - UV-LED lamps controller (PC adapter); III - Magnetic stirrer; IV - Cooling water tank; V - Circulation pump; VI - Air pump; VII - Flow meter; VIII - ; IX - Thermometer; X - Reactor; 1, 2 - Liquid coolant pipeline; 3, 4 - Water pipeline; 5- Air/ozone pipeline. 


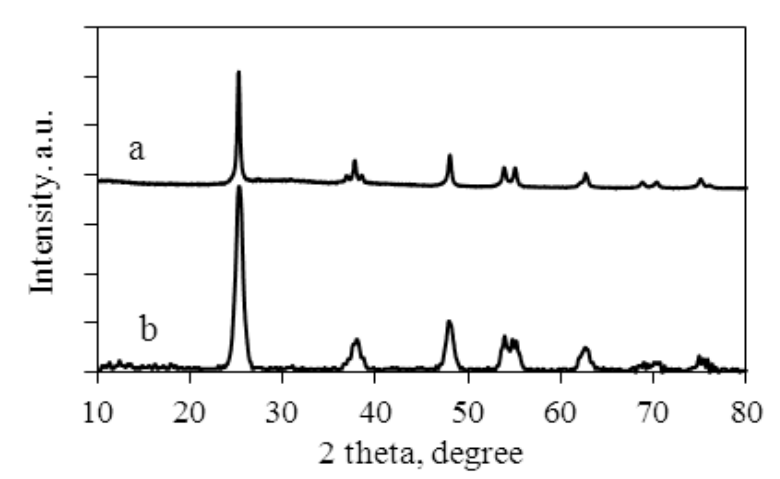

Fig. 2 XRD spectra of $\mathrm{TiO}_{2}$ (a) and $\mathrm{Fe}-\mathrm{TiO}_{2}$ (b) catalysts.

On the Raman spectra of the catalysts (Fig. 3) appeared four characteristic peaks for anatase phase of $\mathrm{TiO}_{2}$ at $153,395,520$ and $643 \mathrm{~cm}^{-1}$. In which, $\mathrm{E}_{\mathrm{g}}$ peaks at $153 \mathrm{~cm}^{-1}$ and $643 \mathrm{~cm}^{-1}, B_{1 \mathrm{~g}}$ at $395 \mathrm{~cm}^{-1}$ and $A_{1 \mathrm{~g}}$ at $520 \mathrm{~cm}^{-1}$ were observed. $E_{\mathrm{g}}$ peaks are formed mainly by fluctuating the symmetric stretch of O-Ti-O in $\mathrm{TiO}_{2}, \mathrm{~B}_{1 \mathrm{~g}}$ peaks are formed by bending oscillation of the O-Ti-O and $\mathrm{A}_{1 \mathrm{~g}}$ are formed by bending the asymmetric oscillation of O-Ti-O [29]. No characteristic peaks of $\mathrm{Fe}_{2} \mathrm{O}_{3}$ or $\mathrm{Fe}_{3} \mathrm{O}_{4}$ was observed that is consistent with the results of the XRD analysis. It indicated that when $\mathrm{Fe}$ ions were incorporated into $\mathrm{TiO}_{2}$ crystal structure, species -TiO-Fe-O-Ti-O- type were formed [30].

It can be found from TEM images (Fig. 4) that both samples consist of pseudo spherical particles, but the particle size of $\mathrm{TiO}_{2}-\mathrm{Fe}$ catalyst was smaller and more uniform than $\mathrm{TiO}_{2}$. Nanoparticle size of $\mathrm{TiO}_{2}$ and $\mathrm{Fe}-\mathrm{TiO}_{2}$ was about $25 \mathrm{~nm}$ and $9.2 \mathrm{~nm}$, respectively. As such, modification $\mathrm{TiO}_{2}$ by $\mathrm{Fe}$ has significantly reduced the size of catalyst particles, leading to an increase in surface area of catalyst from $43.6 \mathrm{~m}^{2} / \mathrm{g}$ to $90.5 \mathrm{~m}^{2} / \mathrm{g}$.

The FT-IR spectra (Fig. 5) of both catalysts showed the characteristic peaks of basic $\mathrm{OH}$-groups on $\mathrm{TiO}_{2}$ surface at $\sim 3,350 \mathrm{~cm}^{-1}$ and adsorbed water molecules $\left(1,630 \mathrm{~cm}^{-1}\right)$. The peaks at $400-700 \mathrm{~cm}^{-1}$ may be attributed to the vibration of Ti-O-Ti and Ti-O or $\mathrm{Fe}-\mathrm{O}$. In comparison with pure $\mathrm{TiO}_{2}, \mathrm{Fe}-\mathrm{TiO}_{2}$ sample showed a higher intensity of the peak corresponding to $\mathrm{OH}$-groups on catalyst surface probably due to its higher surface area, leading to more water adsorbed on the catalyst surface to generate $\mathrm{OH}$-groups.

UV-vis diffuse reflectance spectra of catalysts (Fig. 6)

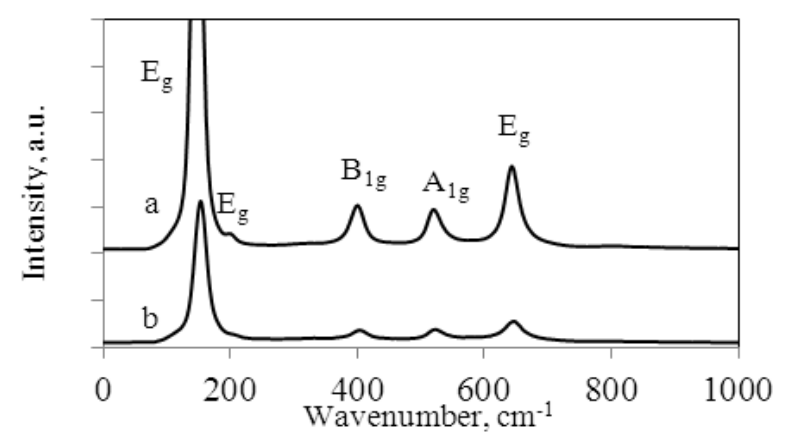

Fig. 3 Raman spectra of $\mathrm{TiO}_{2}$ (a) and $\mathrm{Fe}^{-\mathrm{TiO}_{2}}$ (b) catalysts.

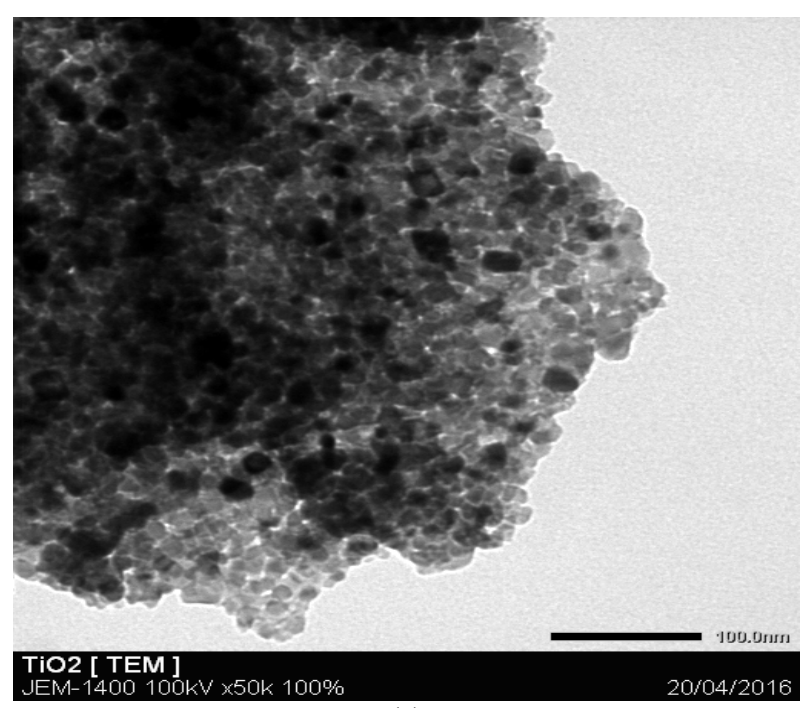

(a)

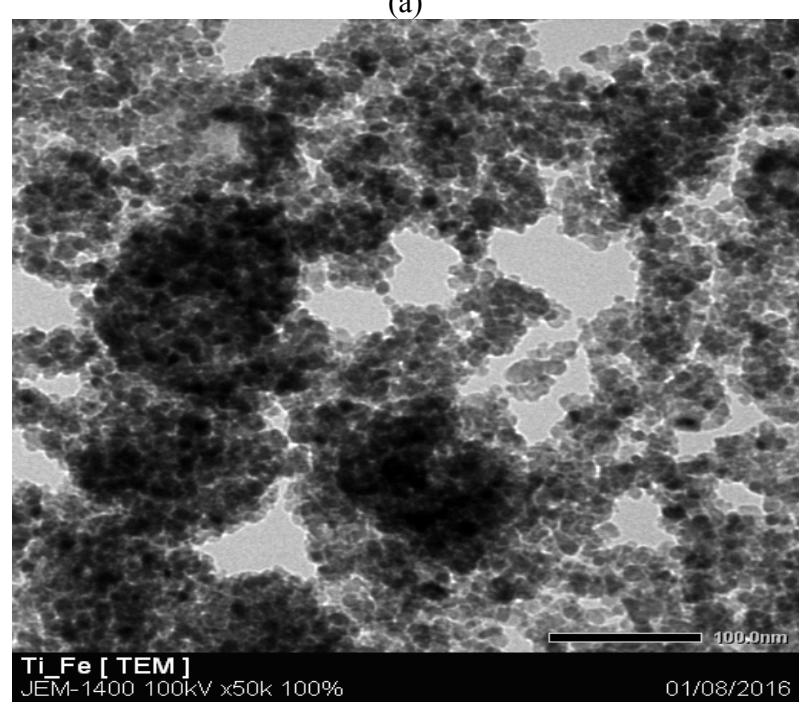

(b)

Fig. 4 TEM images of $\mathrm{TiO}_{2}$ (a) and $\mathrm{Fe}-\mathrm{TiO}_{2}$ (b) catalysts. 

Various Oxidizing Agents on $\mathrm{TiO}_{2}$ and $\mathrm{Fe}-\mathrm{TiO}_{2}$ Catalysts

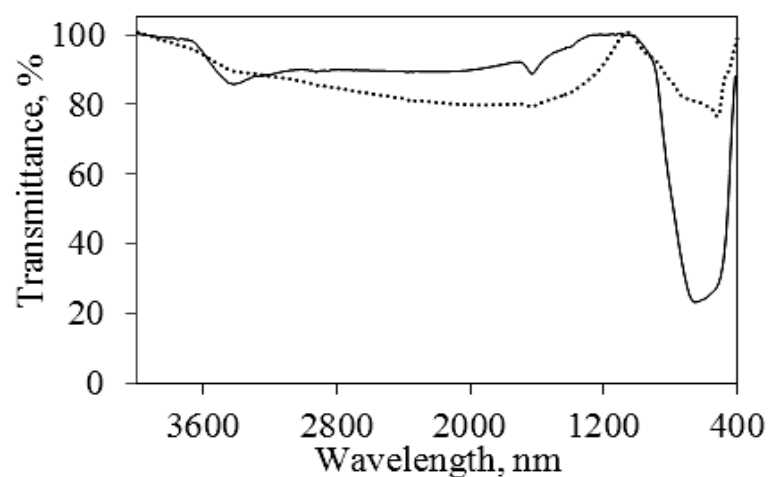

Fig. 5 FT-IR spectra of $\mathrm{TiO}_{2}$ (full line)) and $\mathrm{Fe}^{-\mathrm{TiO}_{2}}$ (dashed line) catalysts.

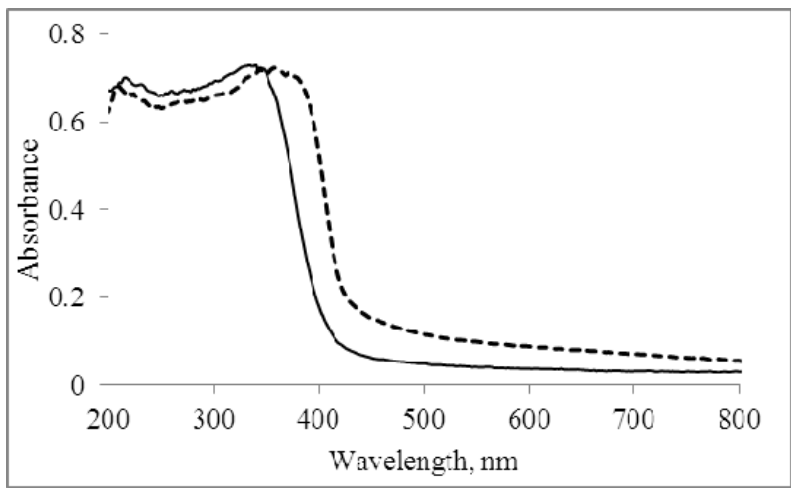

Fig. 6 UV-vis diffuse reflectance spectra of $\mathrm{TiO}_{2}$ (full line) and $\mathrm{Fe}_{-} \mathrm{TiO}_{2}$ (dashed line) catalysts.

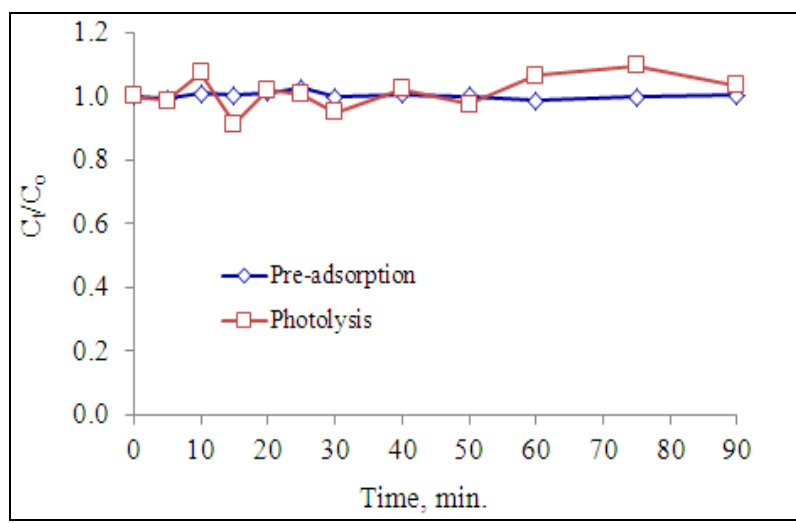

Fig. 7 Pre-adsorption $\left(\mathrm{C}_{\mathrm{cat}}=0.75 \mathrm{~g} / \mathrm{L}\right)$ and photolysis ( $\mathrm{UV}$, $\lambda=365 \mathrm{~nm})$ of cinnamic acid solution on $\mathrm{TiO}_{2}$ catalyst $\left(\mathrm{C}_{\mathrm{CA}}\right.$ $=50 \mathrm{mg} / \mathrm{L}, \mathrm{pH}=7, \mathrm{~T}=25^{\circ} \mathrm{C}, \mathrm{DO}=7,6 \mathrm{mg} / \mathrm{L}$ ).

indicated that iron oxide doped into $\mathrm{TiO}_{2}$ enables to extend the region of the photon absorption zone of $\mathrm{TiO}_{2}$ towards the visible waves (from $\lambda=410 \mathrm{~nm}$ to $437 \mathrm{~nm}$ ) as well as to reduce its band gap energy from $3.03 \mathrm{eV}$ down to $2.87 \mathrm{eV}$. It is also noticeable that pure $\mathrm{TiO}_{2}$ catalyst prepared by the sol-gel method has the lower band gap energy than pure $\mathrm{TiO}_{2}$ anatase and
$\mathrm{TiO}_{2}-\mathrm{P} 25(3.2 \mathrm{eV})[31]$

\subsection{The Pre-adsorption and Photolysis of Cinnamic Acid Solution}

According to Fig. 7, after the pre-adsorption in dark or photolysis (no catalyst, UV lighting) process, CA concentration in the solution stayed nearly unchanged. No adsorption of CA during 90 minutes adsorption process was observed. The effect of UV irradiation alone on the degradation of $\mathrm{CA}$ is also negligible.

\subsection{Activity of Catalysts in Photocatalytic Degradation of Cinnamic Acid}

3.3.1 Photocatalytic Degradation of CA Solution in Presence of Oxygen

According to our previous investigation, the optimal conditions of photocatalytic degradation CA solution in presence of oxygen on pure $\mathrm{TiO}_{2}$ prepared by hydrothermal method $\left(\mathrm{TiO}_{2}(\mathrm{H})\right)$ were determined as follows reaction temperature $25^{\circ} \mathrm{C}$, initial solution $\mathrm{pH}=7, \mathrm{DO}=6.4 \mathrm{mg} / \mathrm{L}$ and catalyst concentration $0.75 \mathrm{~g} / \mathrm{L}$.

Fig. 8 showed that the activity of $\mathrm{TiO}_{2}$ catalyst prepared by the sol-gel method $\left(\mathrm{TiO}_{2}(\mathrm{~S})\right)$ was higher than that of one prepared by the hydrothermal method $\left(\mathrm{TiO}_{2}(\mathrm{H})\right)$. This could be explained that $\mathrm{TiO}_{2}(\mathrm{~S})$ sample existed in the smaller and more uniform particle size (20-25 $\mathrm{nm}$ compare to $30-40 \mathrm{~nm})$ and characterized by the lower band gap energy in comparison with $\mathrm{TiO}_{2}(\mathrm{H})(\mathrm{Eg}=3.14 \mathrm{eV})$. After 90

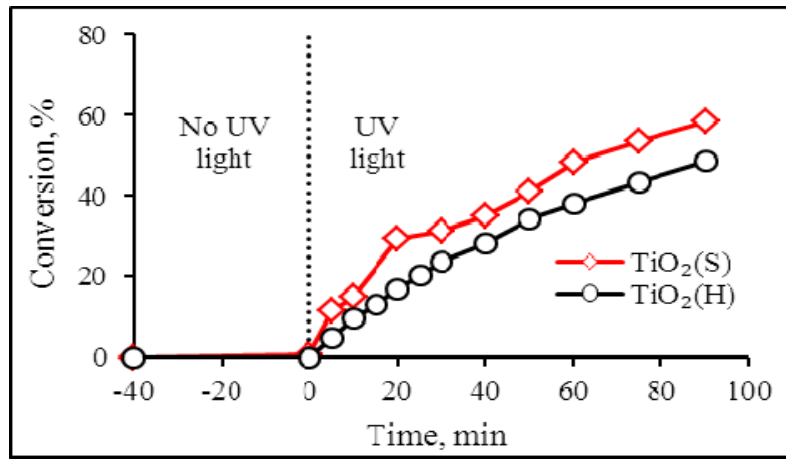

Fig. 8 The conversion of $\mathrm{CA}$ solutions on pure $\mathrm{TiO}_{2}$ catalyst prepared by hydrothermal $\left(\mathrm{TiO}_{2}(\mathrm{H})\right)$ and sol-gel method $\left(\mathrm{TiO}_{2}(\mathrm{~S})\right)$ in presence of $\mathrm{O}_{2}$. 
minutes reaction, CA conversion on $\mathrm{TiO}_{2}(\mathrm{~S})$ and $\mathrm{TiO}_{2}(\mathrm{H})$ catalysts reached $58.5 \%$ and $48.5 \%$, respectively.

On $\mathrm{Fe}-\mathrm{TiO}_{2}$ catalyst, conversion of cinnamic acid decreased with increasing of $\mathrm{pH}$ solution from 3.8 to 7 was observed from Fig. 9a. At pH of 3.8 and 5, the 90 minutes conversion of $\mathrm{CA}\left(\mathrm{X}_{90}\right)$ reached $80.4 \%$ and $75.9 \%$, respectively, meanwhile at $\mathrm{pH}=7$, it reduced to $17 \%$.

The variation of $\mathrm{CA}$ conversion with catalyst concentration has extreme character; the maximum CA conversion after 90 minutes reaction of $80.4 \%$ was observed at $0.75 \mathrm{~g} / \mathrm{L}$ (Fig. 9b).

Fig. 9c showed that CA conversion almost did not change when the dissolved oxygen increased from 5.4 to $6.4 \mathrm{mg} / \mathrm{L}$, the 90 minutes conversion of CA reached approximately $85 \%$. However, when the dissolved oxygen increased up to $7.0 \mathrm{mg} / \mathrm{L}$, CA conversion

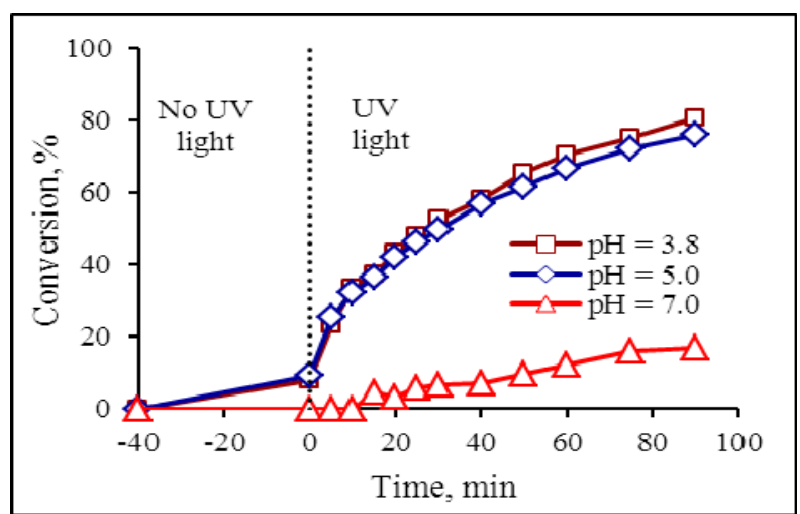

(a) Effect of initial $\mathrm{pH}$ solution $\left(\mathrm{C}_{\mathrm{cat}}=0.75 \mathrm{~g} / \mathrm{L} ; \mathrm{DO}=6.4 \mathrm{mg} / \mathrm{L} ; \mathrm{T}=25^{\circ} \mathrm{C}\right)$

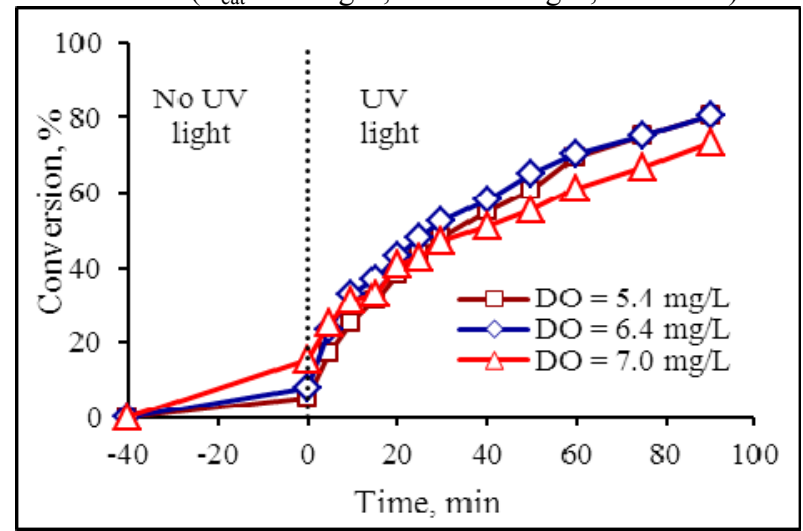

(c) Effect of dissolved oxygen $\left(\mathrm{C}_{\text {cat }}=0.75 \mathrm{~g} / \mathrm{L} ; \mathrm{pH}=3.8 ; \mathrm{T}=25^{\circ} \mathrm{C}\right)$ reduced. Dissolved oxygen plays an important role in $\mathrm{TiO}_{2}$ photocatalytic reaction to assure sufficient electron scavengers present to trap the excited conduction-band electron from the recombination [32]. However, too intensive oxygen flow led to appearance of foams, that on one hand interferes with the absorption of UV light by reaction solution, on the other hand a part of catalyst particles move to the surface of the solution with air bubbles, that reduced the amount of catalyst in solution, in the result efficient handling of CA reduced [33].

Fig. 9d showed that with increasing the reaction temperature CA conversion increased little. The value of $\mathrm{X}_{90}$ reached 80,85 and $87 \%$ corresponding to the reaction temperature 25,30 and $35^{\circ} \mathrm{C}$. Therefore, the ambient temperature of $30^{\circ} \mathrm{C}$ was chosen for the $\mathrm{CA}$ photodegradation with oxygen agent on $\mathrm{Fe}-\mathrm{TiO}_{2}$ catalyst.

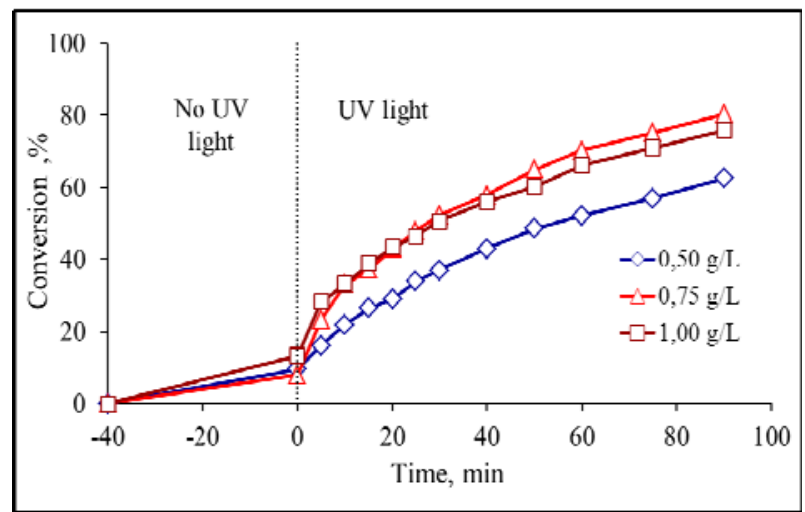

(b) Effect of catalyst concentration $\left(\mathrm{DO}=6.4 \mathrm{mg} / \mathrm{L} ; \mathrm{pH}=3.8 ; \mathrm{T}=25^{\circ} \mathrm{C}\right)$

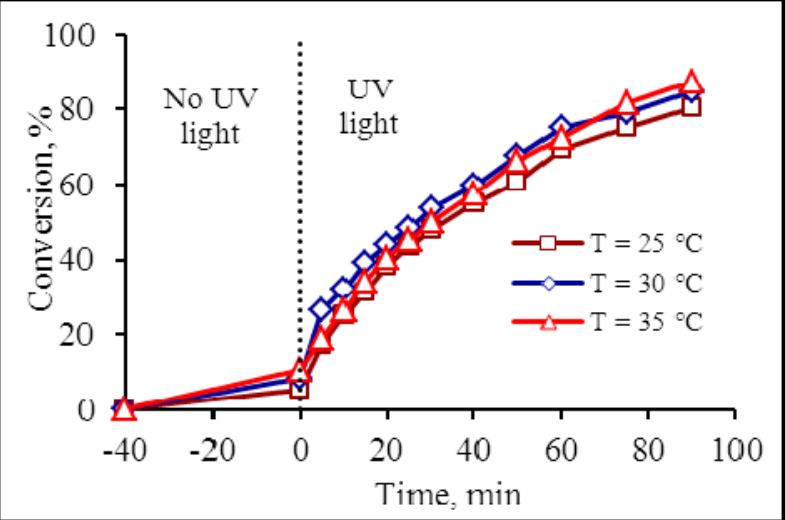

(d) Effect of reaction temperature $\left(\mathrm{C}_{\mathrm{cat}}=0.75 \mathrm{~g} / \mathrm{L} ; \mathrm{DO}=5.4 \mathrm{mg} / \mathrm{L} ; \mathrm{pH}=3.8\right)$

Fig. 9 The conversion of $\mathrm{CA}$ solutions on $\mathrm{Fe}^{-\mathrm{TiO}_{2}}$ catalyst in presence of $\mathrm{O}_{2}$. 
3.3.2 Photocatalytic Degradation of CA Solution in Presence of Ozone

Figs. 10 and 11 showed that compared to oxygen oxidant ozone had not only significantly reduced the concentration of used catalysts but also increased CA conversion. On $\mathrm{TiO}_{2}$ catalyst, CA conversion rise from $59 \%$ to $82 \%$ when the flow rate of $\mathrm{O}_{3}$ increased from 0.1 to $0.5 \mathrm{~L} / \mathrm{min}$ (seen in Fig. 10(a)), but if ozone flow was still increased to $0.7 \mathrm{~L} / \mathrm{min}$, a decrease of $\mathrm{X}_{90}$ down to $\sim 79 \%$ was observed. This may be due to ozone supporting the production of $\mathrm{O}_{2}$ and $\mathrm{OH}^{*}$ radicals (Eqs. (1)-(4)) [34]. However, excess $\mathrm{O}_{3}$ reacts

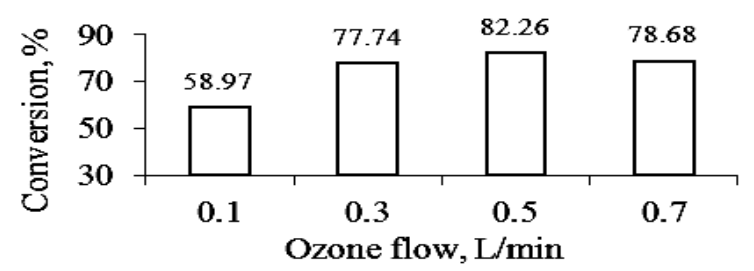

(a)

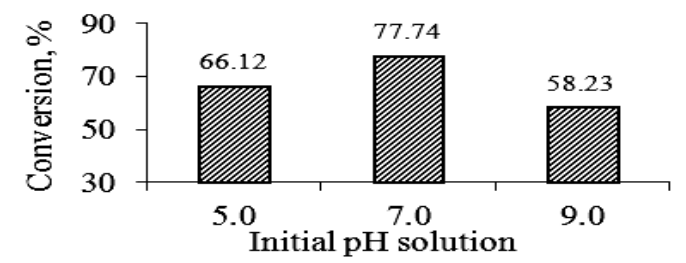

(a) with $\mathrm{OH}^{*}$ radicals to reduce the amount of radicals (Eq. 5) [35], leading to drop CA conversion.

$$
\begin{gathered}
\mathrm{TiO}_{2}+\mathrm{h} v \rightarrow \mathrm{e}^{-}+\mathrm{h}^{+} \\
\mathrm{O}_{3}+\mathrm{e}^{-} \rightarrow \mathrm{O}_{3}^{*-} \\
\mathrm{O}_{3}^{*-}+\mathrm{H}^{+} \rightarrow \mathrm{HO}_{3}^{*} \\
\mathrm{HO}_{3}^{*} \rightarrow \mathrm{O}_{2}+\mathrm{OH}^{*} \\
\mathrm{OH}^{*}+\mathrm{O}_{3} \rightarrow \mathrm{O}_{2}+\mathrm{HOO}^{*}
\end{gathered}
$$

Fe- $\mathrm{TiO}_{2}$ catalyst exhibited the higher photoactivity than $\mathrm{TiO}_{2}$ and it reached the maximum CA conversion

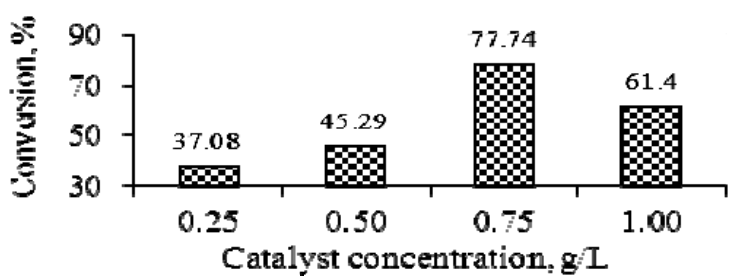

(b)

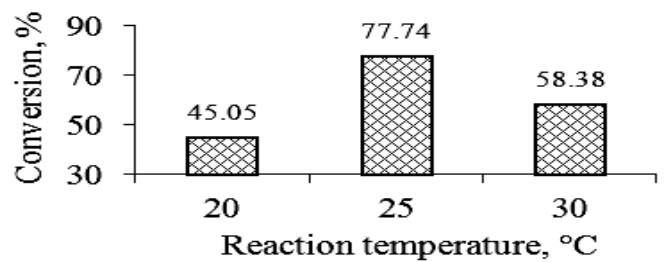

(b)

Fig. 10 The conversion of $\mathrm{CA}$ solutions on $\mathrm{TiO}_{2}$ catalyst in presence of ozone: (a) effect of ozone flow $\left(\mathrm{C}_{\mathrm{cat}}=0.75 \mathrm{~g} / \mathrm{L}, \mathrm{pH}=7\right.$, $\left.\mathrm{T}=25^{\circ} \mathrm{C}\right)$, (b) effect of catalyst concentration $\left(\mathrm{Q}_{\text {ozone }}=0.3 \mathrm{~L} / \mathrm{min}, \mathrm{pH}=7, \mathrm{~T}=25^{\circ} \mathrm{C}\right)$, (c) Effect of initial $\mathrm{pH}$ solution $\left(\mathrm{C}_{\mathrm{cat}}=\right.$ $\left.0.75 \mathrm{~g} / \mathrm{L}, Q_{\text {ozone }}=0.3 \mathrm{~L} / \mathrm{min}, \mathrm{T}=25^{\circ} \mathrm{C}\right)$ and $(\mathrm{d})$ effect of reaction temperature $\left(\mathrm{C}_{\text {cat }}=0.75 \mathrm{~g} / \mathrm{L}, \mathrm{Q}_{\text {ozone }}=0.3 \mathrm{~L} / \mathrm{min}, \mathrm{pH}=7\right)$.

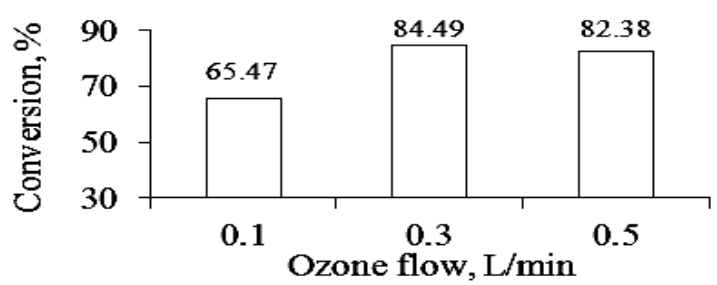

(a)

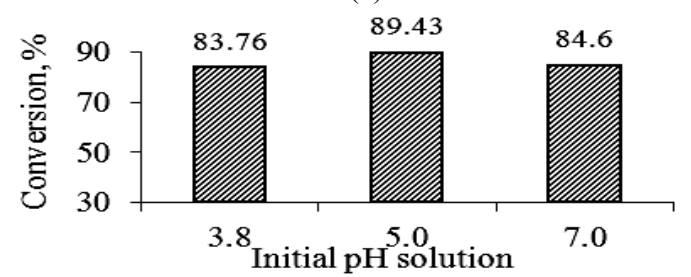

(a)

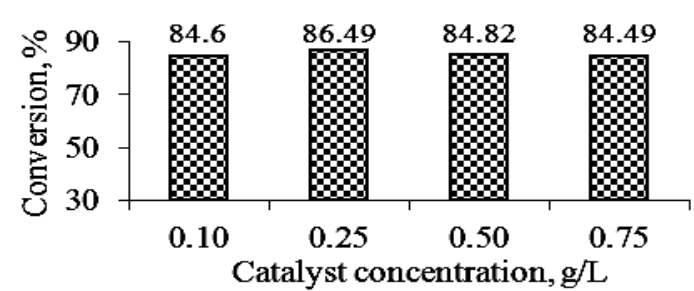

(b)

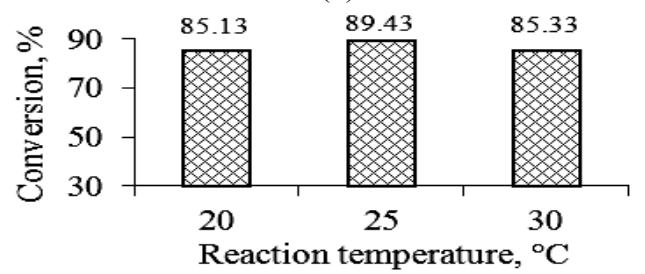

(b)

Fig. 11 The conversion of $\mathrm{CA}$ solutions on $\mathrm{Fe}^{-\mathrm{TiO}_{2}}$ catalyst in presence of ozone: (a) effect of ozone flow $\left(\mathrm{C}_{\text {cat }}=0.75 \mathrm{~g} / \mathrm{L}\right.$, $\mathrm{pH}$ $\left.=7, \mathrm{~T}=25^{\circ} \mathrm{C}\right)$, (b) effect of catalyst concentration $\left(\mathrm{Q}_{\mathrm{ozone}}=0.3 \mathrm{~L} / \mathrm{min}, \mathrm{pH}=7, \mathrm{~T}=25^{\circ} \mathrm{C}\right)$, (c) effect of initial $\mathrm{pH}$ solution $\left(\mathrm{C}_{\mathrm{cat}}\right.$ $\left.=0.75 \mathrm{~g} / \mathrm{L}, \mathrm{Q}_{\text {ozone }}=0.3 \mathrm{~L} / \mathrm{min}, \mathrm{T}=25^{\circ} \mathrm{C}\right)$ and $(\mathrm{d})$ effect of reaction temperature $\left(\mathrm{C}_{\text {cat }}=0.1 \mathrm{~g} / \mathrm{L}, \mathrm{Q}_{\text {ozone }}=0.3 \mathrm{~L} / \mathrm{min}, \mathrm{pH}=5\right)$. 
about $85 \%$ at as low $\mathrm{O}_{3}$ flow rate as $0.3 \mathrm{~L} / \mathrm{min}$ (Fig. 11a). This may due to the facts that the energy level for $\mathrm{Fe}^{3+} / \mathrm{Fe}^{4+}$ is above the valence band edge of $\mathrm{TiO}_{2}$ and the energy level for $\mathrm{Fe}^{3+} / \mathrm{Fe}^{2+}$ is below the conduction band edge of $\mathrm{TiO}_{2}[36], \mathrm{Fe}^{3+}$ ions acting as both electrons and holes traps can turn into $\mathrm{Fe}^{2+}$ and $\mathrm{Fe}^{4+}$ ions by trapping photogenerated electrons and holes, respectively. $\mathrm{Fe}^{2+}$ ions can be oxided to $\mathrm{Fe}^{3+}$ ions by transferring electrons to absorbed $\mathrm{O}_{2}$ on the surface of $\mathrm{TiO}_{2}$ or a neighboring surface $\mathrm{Ti}^{4+}$ ions [37]. Meanwhile, the adsorbed $\mathrm{O}_{2}$ is reduced to $\mathrm{O}^{2-}$, which can further degrade CA. Similarly, $\mathrm{Fe}^{4+}$ ions also are reduced to $\mathrm{Fe}^{3+}$ ions by releasing electrons, while surface hydroxyl group translates into $\mathrm{OH}^{*}$ radical. As a result, the introduction of appropriate $\mathrm{Fe}^{3+}$ ions is responsible for the reduction of the photogenerated hole-electron recombination rate and favors the improvement of photocatalytic activity. However, $\mathrm{Fe}^{3+}$ ion can act as the recombination centers for the photogenerated electrons and holes when $\mathrm{Fe}^{3+}$ ion concentration becomes high, lead to the decrease of photocatalytic activity. In our case the optimal doping concentration is $0.1 \%$. Above that concentration, $\mathrm{Fe}^{3+}$ ion steadily become recombination centers and the photocatalytic activity gradually decreases [38].

With increasing catalysts concentration, CA conversion increased strongly on pure $\mathrm{TiO}_{2}$ (Fig. 10b), meanwhile it just did slightly on $\mathrm{Fe}$ doped- $\mathrm{TiO}_{2}$ (Fig. 11b). Thereby, it reducing significantly the required concentration of catalyst, thanks to the reduction of the particle size and the increase of specific surface area, moreover, the appearance $\mathrm{Fe}^{3+}$ ions motived the formation of radicals $\mathrm{O}^{2-}, \mathrm{HOO}^{*}$ and $\mathrm{OH}^{*}$, leading to intensify the activity of $\mathrm{TiO}_{2}-\mathrm{Fe}$ catalyst.

Like the case of using oxygen as oxidant in this case on pure $\mathrm{TiO}_{2}$ the $\mathrm{CA}$ conversion at $\mathrm{pH}=7$ was higher than that at $\mathrm{pH}=5$ and 9 (Fig. 10c), meanwhile, on $\mathrm{Fe}$ - doped $\mathrm{TiO}_{2}$, the conversion of $\mathrm{CA}$ is highest at acidic solution $\mathrm{pH}=5$ (Fig. 11c) were observed. Thus, doped $\mathrm{Fe}$ to $\mathrm{TiO}_{2}$ not only increases the photocatalytic activity, but also alters the value of optimal initial $\mathrm{pH}$ of solution from neutral to acidic. This may due with the point of zero charge (PZC) of obtained $\mathrm{TiO}_{2}$ and $\mathrm{Fe}-\mathrm{TiO}_{2}$ was found of $\sim 7.36$ and 4.87 respectively. According to reports [39-41] the point of zero charge of $\mathrm{TiO}_{2}$ is the range of 4.5-7.0. At PZC point the interaction between the catalyst particles and CA solution is minimal due to the absence of any electrostatic force. When solution $\mathrm{pH}$ was below PZC, the catalyst surface of $\mathrm{TiO}_{2}$ becomes positively charged (i.e. $\mathrm{TiOH}+\mathrm{H}^{+} \leftrightarrow \mathrm{TiOH}_{2}{ }^{+}$) and gradually exerted an electrostatic attraction force towards the negatively charged compounds. Such polar attractions between $\mathrm{TiO}_{2}$ and charged anionic organic compounds can intensify the adsorption onto the photon activated $\mathrm{TiO}_{2}$ surface for subsequent photocatalytic reactions [42]. At solution $\mathrm{pH}>\mathrm{PZC}$, the catalyst surface will be negatively charged (i.e. $\left.\mathrm{TiOH}+\mathrm{OH}^{-} \leftrightarrow \mathrm{TiO}^{-}+\mathrm{H}_{2} \mathrm{O}\right)$ and repulse the anionic compounds in water. Different $\mathrm{pH}$ will affect the surface charge density of $\mathrm{TiO}_{2}$ catalyst [43].

$\mathrm{Fe}-\mathrm{TiO}_{2}$ catalyst favorable working in an acid environment can also cause it having higher activity than pure $\mathrm{TiO}_{2}$. Because in acidic solution the quantity of $\mathrm{H}^{+}$ions is much higher than that one with $\mathrm{pH}=7$, $\mathrm{H}^{+}$ions should be able to combine with $\mathrm{O}^{2-}$ radicals to generate HOO* radicals (Eqs. (6) and (7)) [44].

$$
\begin{aligned}
\mathrm{TiO}_{2}\left(\mathrm{e}^{-}\right)+\mathrm{O}_{2} & \rightarrow \mathrm{O}^{2-}+\mathrm{TiO}_{2} \\
\mathrm{O}^{2-}+\mathrm{H}^{+} & \rightarrow \mathrm{HOO}^{*}
\end{aligned}
$$

Moreover, the $\mathrm{pK}_{\mathrm{a}}$ of CA is 4.4 [45], lower $\mathrm{pH}$ is consistent for the its photodegradation.

3.3.3 Photocatalytic Degradation of CA Solution in Presence of $\mathrm{H}_{2} \mathrm{O}_{2}$.

The influences of condition the CA conversion after 90 minutes reaction on both catalysts in the presence of $\mathrm{H}_{2} \mathrm{O}_{2}$ were shown in Figs. 12 and 13.

The optimal conditions for CA photodegradation on both catalysts with various oxidizing agents are summarized in Table 1.

Figs. 12, 13 and Table 1 showed that on pure $\mathrm{TiO}_{2}$ catalyst in comparison with other oxidants $\left(\mathrm{O}_{2}, \mathrm{O}_{3}\right), \mathrm{H}_{2} \mathrm{O}_{2}$ 

Various Oxidizing Agents on $\mathrm{TiO}_{2}$ and $\mathrm{Fe}-\mathrm{TiO}_{2}$ Catalysts

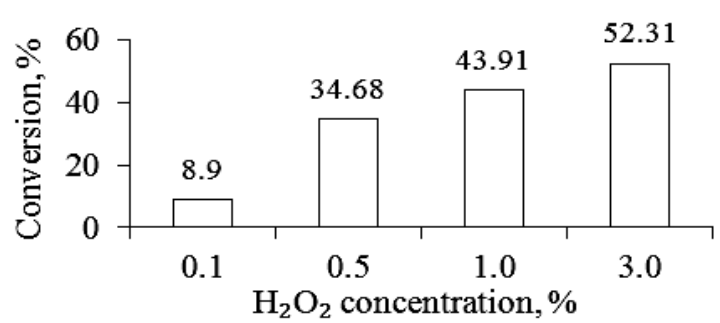

(a)

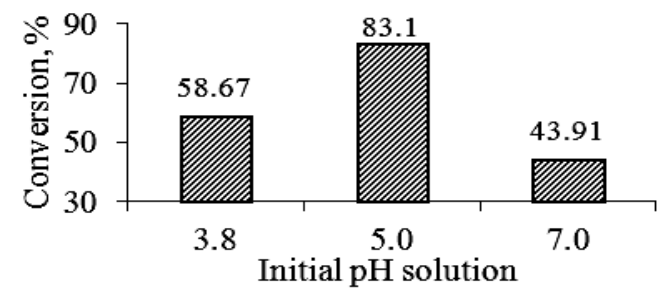

(c)

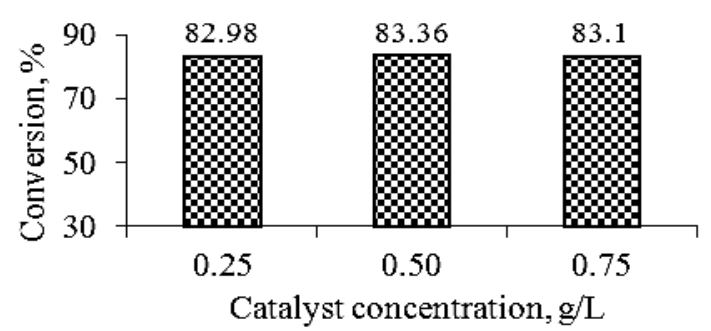

(b)

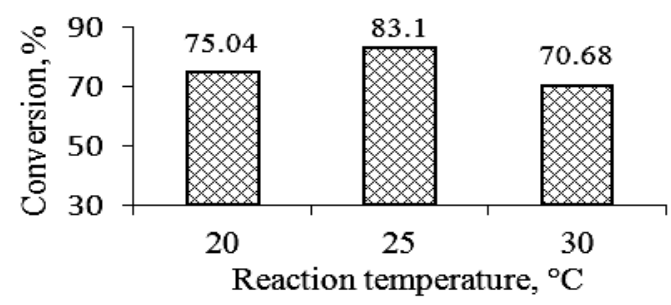

(d)

Fig. 12 The conversion of CA solutions on $\mathrm{TiO}_{2}$ catalyst in presence of $\mathrm{H}_{2} \mathrm{O}_{2}$ : (a) effect of $\mathrm{H}_{2} \mathrm{O}_{2}$ concentration $\left(\mathrm{C}_{\text {cat }}=0.75 \mathrm{~g} / \mathrm{L}\right.$, $\left.\mathrm{pH}=7, \mathrm{~T}=25^{\circ} \mathrm{C}\right)$, (b) effect of catalyst concentration $\left(\mathrm{H}_{2} \mathrm{O}_{2}=1 \%, \mathrm{pH}=5, \mathrm{~T}=25^{\circ} \mathrm{C}\right),(\mathrm{c})$ effect of initial $\mathrm{pH}$ solution $\left(\mathrm{C}_{\mathrm{cat}}=\right.$ $\left.0.75 \mathrm{~g} / \mathrm{L}, \mathrm{H}_{2} \mathrm{O}_{2}=1 \%, \mathrm{~T}=25^{\circ} \mathrm{C}\right)$ and (d) effect of temperature reaction $\left(\mathrm{C}_{\mathrm{cat}}=0.75 \mathrm{~g} / \mathrm{L}, \mathrm{H}_{2} \mathrm{O}_{2}=1 \%, \mathrm{pH}=5\right)$.

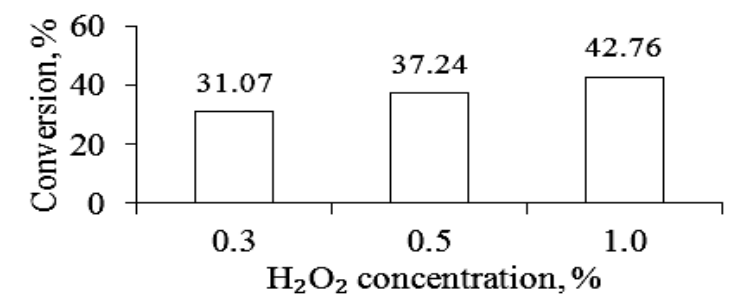

(a)

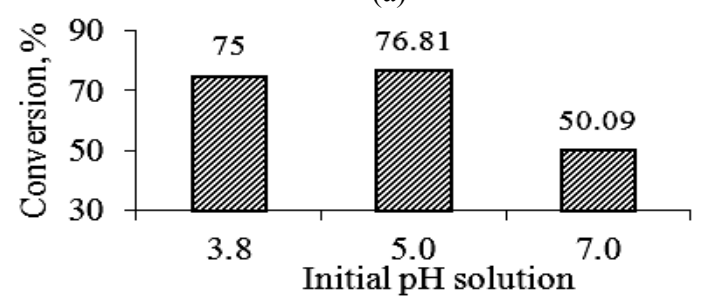

(c)

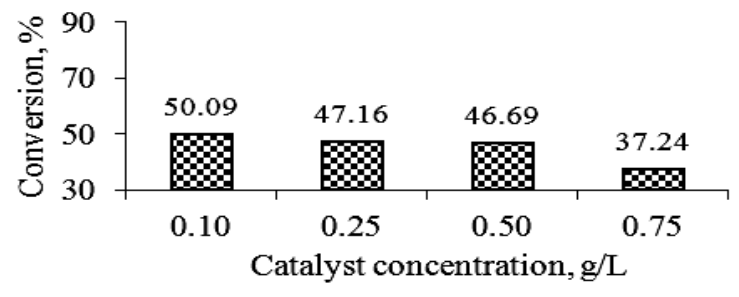

(b)

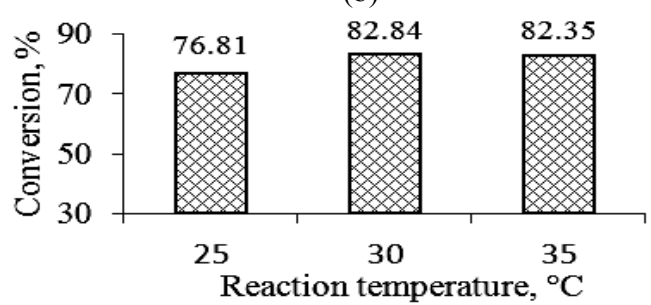

(d)

Fig. 13 The conversion of $\mathrm{CA}$ solutions on $\mathrm{Fe}-\mathrm{TiO}_{2}$ catalyst in presence of $\mathrm{H}_{2} \mathrm{O}_{2}$ : (a) effect of $\mathrm{H}_{2} \mathrm{O}_{2}$ concentration $\left(\mathrm{C}_{\text {cat }}=0.75\right.$ $\left.\mathrm{g} / \mathrm{L}, \mathrm{pH}=7, \mathrm{~T}=25^{\circ} \mathrm{C}\right)$, (b) effect of catalyst concentration $\left(\mathrm{H}_{2} \mathrm{O}_{2}=0.5 \%, \mathrm{pH}=7, \mathrm{~T}=25^{\circ} \mathrm{C}\right)$, (c) effect of initial pH solution $\left(\mathrm{C}_{\text {cat }}=0.1 \mathrm{~g} / \mathrm{L}, \mathrm{H}_{2} \mathrm{O}_{2}=0.5 \%, \mathrm{~T}=25^{\circ} \mathrm{C}\right)$ and (d) effect of temperature reaction $\left(\mathrm{C}_{\text {cat }}=0.1 \mathrm{~g} / \mathrm{L}, \mathrm{H}_{2} \mathrm{O}_{2}=0.5 \%, \mathrm{pH}=5\right)$.

Table 1 The optimal conditions for $\mathrm{CA}$ photodegradation on $\mathrm{TiO}_{2}$ - based catalysts using various oxidizing agents.

\begin{tabular}{lllllll}
\hline Catalyst & Oxidizing agent & Temperature $\left({ }^{\circ} \mathrm{C}\right)$ & $\begin{array}{l}\text { Catalyst concentration Value of Oxidizing } \\
(\mathrm{g} / \mathrm{L})\end{array}$ & $\begin{array}{l}\text { PH solution } \\
\text { agent }\end{array}$ & $\begin{array}{l}\text { Conversion after } \\
90 \text { minutes }(\%)\end{array}$ \\
\hline \multirow{2}{*}{$\mathrm{TiO}_{2}$} & $\mathrm{O}_{2}$ & 25 & 0.75 & $6.4 \mathrm{mg} / \mathrm{L}$ & 7 & 58.5 \\
& $\mathrm{O}_{3}$ & 25 & 0.75 & $0.3 \mathrm{~L} / \mathrm{min}$ & 7 & 77.7 \\
& $\mathrm{H}_{2} \mathrm{O}_{2}$ & 25 & 0.50 & $1 \%$ & 5 & 83.1 \\
\hline \multirow{2}{*}{$\mathrm{Fe}-\mathrm{TiO}_{2}$} & $\mathrm{O}_{2}$ & 30 & 0.75 & $5.4 \mathrm{mg} / \mathrm{L}$ & 3.8 & 84.8 \\
& $\mathrm{O}_{3}$ & 25 & 0.1 & $0.3 \mathrm{~L} / \mathrm{min}$ & 5 & 89.5 \\
& $\mathrm{H}_{2} \mathrm{O}_{2}$ & 30 & 0.1 & $0.5 \%$ & 5 & 82.9 \\
\hline
\end{tabular}


gave higher CA conversion and required lower catalyst concentration. This can be explained by that $\mathrm{H}_{2} \mathrm{O}_{2}$ creating double $\mathrm{OH}^{*}$ radicals (Eqs. (8) and (9)) [46].

$$
\begin{aligned}
\mathrm{e}^{-}+\mathrm{H}_{2} \mathrm{O}_{2} & \rightarrow \mathrm{OH}^{*}+\mathrm{OH}^{-} \\
\mathrm{h}^{+}+\mathrm{HO}_{2} & \rightarrow \mathrm{OH}^{*}+\mathrm{H}^{+}
\end{aligned}
$$

Figs. 12 and 13 showed that at the optimal reaction conditions with the same oxidizing agent $\mathrm{H}_{2} \mathrm{O}_{2}$, to achieve the same CA conversion $(\sim 83 \%)$ the concentration of catalyst and $\mathrm{H}_{2} \mathrm{O}_{2}$ in the case of using $\mathrm{Fe}-\mathrm{TiO}_{2}$ were much lower than those in case of using pure $\mathrm{TiO}_{2}$ catalyst (seen in Table 1). The simultaneous presence of $\mathrm{Fe}^{3+}$ ions in the catalyst and $\mathrm{H}_{2} \mathrm{O}_{2}$ in reaction solution creating favorable conditions to increase the production of $\mathrm{OH}^{*}$ radicals by Fenton reaction (Eq. (10)) [46], but when concentration of $\mathrm{Fe}^{2+}$ ions was too much the amount of radical $\mathrm{OH}^{*}$ reduced in the result of reaction (11) [47].

$$
\begin{gathered}
\mathrm{Fe}^{2+}+\mathrm{H}_{2} \mathrm{O}_{2} \rightarrow \mathrm{Fe}^{3+}+\mathrm{OH}^{*}+\mathrm{OH}^{-} \\
\mathrm{Fe}^{2+}+\mathrm{OH}^{*} \rightarrow \mathrm{Fe}^{3+}+\mathrm{OH}^{-}
\end{gathered}
$$

Overall, the doping $\mathrm{TiO}_{2}$ by Fe leads to reduce the needed concentration of catalyst and oxidants, increasing CA conversion and allowing reactions proceed in acidic environment, the natural environment of the solution CA. In the photodegradation of $\mathrm{CA}$, the absorption of $\mathrm{CA}$ on surface catalysts is medium.

\section{Conclusions}

Doping $\mathrm{Fe}$ to $\mathrm{TiO}_{2}$ causes the particle size reduction, red shift the photon absorbing zone of $\mathrm{TiO}_{2}$ and reduce its band gap energy from $3.03 \mathrm{eV}$ to 2.87 $\mathrm{eV}$ that increased the photoactivity of $\mathrm{Fe}-\mathrm{TiO}_{2}$ catalyst. Using Fe-doped $\mathrm{TiO}_{2}$ catalyst is able to reduce the optimal catalyst concentration 3-5 times, reduce oxidant concentration, increase catalytic activity and allows reaction process in acidic environment.

$\mathrm{O}_{3}$ and $\mathrm{H}_{2} \mathrm{O}_{2}$ agents showed higher efficiency for cinnamic acid photodecomposition than usual $\mathrm{O}_{2}$ under UV-A light. In optimum conditions, after 90 minutes reaction, the conversion of cinnamic acid achieved $59-83 \%$ on $\mathrm{TiO}_{2}$ and on $\mathrm{Fe}-\mathrm{TiO}_{2}$ the $\mathrm{CA}$ conversion in reaction with all three oxidizing agents $\left(\mathrm{O}_{2}, \mathrm{O}_{3}\right.$ and $\left.\mathrm{H}_{2} \mathrm{O}_{2}\right)$ reached nearly $90 \%$.

The results contributed to emphasize that pure $\mathrm{TiO}_{2}$ and $\mathrm{Fe}$ doped $\mathrm{TiO}_{2}$ catalysts prepared by sol-gel method have the great potential in photodecomposition of ring compounds and recalcitrant surfactants.

\section{Acknowledgements}

This work was supported by the Ho Chi Minh City University of Technology, Vietnam National University-Ho Chi Minh City (VNU-HCM) under the grant "Investigation of photo-degradation of phenolic compounds in water using $\mathrm{TiO}_{2}$ catalyst" and grand PCATDES 309846 of Seventh Framework Programme- European Commission.

\section{References}

[1] Schneider, J., Matsuoka, M., Takeuchi, M., Zhang, J., Horiuchi, Y., and Anpo, M. 2014. "Understanding $\mathrm{TiO}_{2}$ Photocatalysis: Mechanisms and Materials." Chemical Reviews 114: 9919-86.

[2] Malato, S., Fernandez-Ibanez, P., Maldonado, M. I. and Blanco, J. 2009. "Decontamination and Disinfection of Water by Solar Photocatalysis: Recent Overview and Trends." Catalysis Today 147: 1-59.

[3] Luu, C. L., Nguyen, Q. T. and Ho, S. T. 2010. "Synthesis and Characterization of Fe-Doped $\mathrm{TiO}_{2}$ Photocatalyst by the Sol-Gel Method." Adv. Nat. Sci., Nanosci. Nanotechnol. 1: 015008.

[4] Saratale, R. G., Noh, H. S., Song, J. Y. and Kim, D. S. 2014. "Influence of Parameters on the Photocatalytic Degradation of Phenolic Contaminants in Wastewater Using $\mathrm{TiO}_{2} / \mathrm{UV}$ System." Journal of Environmental Science and Health, Part A 49: 1542-52.

[5] Ahmed, S., Rasul, M. G., Brown, R. and Hashib, M. A. 2011. "Influence of Parameters on the Heterogeneous Photocatalytic Degradation of Pesticides and Phenolic Contaminants in Wastewater: A Short Review.” Journal of Environmental Management 92: 311-30.

[6] Dobrosz-Gómez, I., Gómez-García, M. Á., López Zamora, S. M., GilPavas, E. , Bojarska, J. and Kozanecki, M. 2015. "Transition Metal Loaded $\mathrm{TiO}_{2}$ for Phenol Photo-Degradation." Comptes Rendus Chimie 18: 1170-82.

[7] Rahman, M. A. and Muneer, M. 2005. "Photocatalysed 


\section{Photodegradation of Cinnamic Acid Solution in the Presence of Various Oxidizing Agents on $\mathrm{TiO}_{2}$ and $\mathrm{Fe}-\mathrm{TiO}_{2}$ Catalysts}

Degradation of Two Selected Pesticide Derivatives, Dichlorvos and Phosphamidon, in Aqueous Suspensions of Titanium Dioxide.” Desalination 181: 161-72.

[8] Rahman, M. A., Muneer, M. and Bahnemann, D. 2002. "Photocatalysed Degradation of a Herbicide Derivative, Diphenamid in Aqueous Suspension of Titanium Dioxide." Journal of Advanced Oxidation Technologies 6: $100-8$.

[9] Qamar, M. and Muneer, M. 2005. "Comparative Photocatalytic Study of Two Selected Pesticide Derivatives, Indole-3-Acetic Acid and Indole-3-Butyric Acid in Aqueous Suspensions of Titanium Dioxide." Journal of Hazardous Materials 120: 219-27.

[10] Chen, J. Q., Wang, D., Zhu, M. X. and Gao, C. J. 2007. "Photocatalytic Degradation of Dimethoate Using Nanosized $\mathrm{TiO}_{2}$ Powder." Desalination 207: 87-94.

[11] Muneer, M., Qamar, M., Saquib, M. and Bahnemann, D. W. 2005. "Heterogeneous Photocatalysed Reaction of Three Selected Pesticide Derivatives, Propham, Propachlor and Tebuthiuron in Aqueous Suspensions of Titanium Dioxide." Chemosphere 61: 457-68.

[12] Pino, E. and Encinas, M. V. 2012. "Photocatalytic Degradation of Chlorophenols on $\mathrm{TiO}_{2}-325$ Mesh and $\mathrm{TiO}_{2}-\mathrm{P} 25$. An Extended Kinetic Study of Photodegradation under Competitive Conditions." Journal of Photochemistry and Photobiology A: Chemistry 242: 20-7.

[13] Miranda-García, N., Suárez, S., Sánchez, B., Coronado, J. M., Malato, S. and Maldonado, M. I. 2011. "Photocatalytic Degradation of Emerging Contaminants in Municipal Wastewater Treatment Plant Effluents Using Immobilized $\mathrm{TiO}_{2}$ in a Solar Pilot Plant.” Applied Catalysis B: Environmental 103: 294-301.

[14] Jallouli, N., Elghniji, K., Trabelsi, H. and Ksibi, M. 2014. "Photocatalytic Degradation of Paracetamol on $\mathrm{TiO}_{2}$ Nanoparticles and $\mathrm{TiO}_{2} /$ Cellulosic Fiber under UV and Sunlight Irradiation." Arabian Journal of Chemistry http://dx.doi.org/10.1016/j.arabjc.2014.03.014.

[15] Nawawi W. I. and Nawi, M. A. 2014. "Carbon Coated Nitrogen Doped P25 for the Photocatalytic Removal of Organic Pollutants under Solar and Low Energy Visible Light Irradiations." Journal of Molecular Catalysis A: Chemical 383-384: 83-93.

[16] Sahel, K., Bouhent, M., Belkhadem, F., Ferchichi, M., Dappozze, F. and Guillard, C. 2014. "Photocatalytic Degradation of Anionic and Cationic Dyes over $\mathrm{TiO}_{2}-\mathrm{P} 25$, and Ti-Pillared Clays and Ag-Doped Ti-Pillared Clays.” Applied Clay Science 95: 205-10.

[17] Sangchay, W., Sikong, L. and Kooptarnond, K. 2012. "Comparison of Photocatalytic Reaction of Commercial P25 and Synthetic $\mathrm{TiO}_{2}-\mathrm{AgCl}$ Nanoparticles." Procedia Engineering 32: 590-6.
[18] Oshani, F., Marandi, R., Rasouli, S. and Farhoud, M. K. 2014. "Photocatalytic Investigations of $\mathrm{TiO}_{2}-\mathrm{P} 25$ Nanocomposite Thin Films Prepared by Peroxotitanic Acid Modified Sol-Gel Method." Applied Surface Science 311: 308-13.

[19] Fan, H. J., Lu, C. S., Lee, W. L. W., Chiou, M. R. and Chen, C. C. 2011. "Mechanistic Pathways Differences between $\mathrm{P}_{25}-\mathrm{TiO}_{2}$ and $\mathrm{Pt}-\mathrm{TiO}_{2}$ Mediated $\mathrm{CV}$ Photodegradation." Journal of Hazardous Materials 185: 227-35.

[20] Ljubas, D., Smoljanić, G. and Juretić, H. 2015. "Degradation of Methyl Orange and Congo Red Dyes by Using $\mathrm{TiO}_{2}$ Nanoparticles Activated by the Solar and the Solar-Like Radiation." Journal of Environmental Management 161: 83-91.

[21] Abramović, B., Šojić, D., Despotović, V., Vione, D., Pazzi, M. and Csanádi, J. 2011. "A Comparative Study of the activity of $\mathrm{TiO}_{2}$ Wackherr and Degussa P25 in the Photocatalytic Degradation of Picloram." Applied Catalysis B: Environmental 105: 191-8.

[22] Madani, M. E., Harir, M., Zrineh, A. and Azzouzi, M. E. 2015. "Photodegradation of Imazethapyr Herbicide by Using Slurry and Supported $\mathrm{TiO}_{2}$ : Efficiency Comparison." Arabian Journal of Chemistry 8: 181-5.

[23] Deeb, A. A., Fayyad, M. K. and Alawi, M. A. 2012. "Separation of Polyphenols from Jordanian Olive Oil Mill Wastewater." Chromatography Research International, doi:10.1155/2012/812127.

[24] Mantzavinos, D. 2003. "Removal of Cinnamic Acid Derivatives from Aqueous Effluents by Fenton and Fenton-Like Processes as an Alternative to Direct Biological Treatment." Water, Air, and Soil Pollution Focus 3: 211-21.

[25] Zhu, X., Wang, Y., Qin, W., Zhang, S. and Zhou, D. 2016. "Distribution of free Radicals and Intermediates during the Photodegradation of Polychlorinated Biphenyls Strongly Affected by Cosolvents and $\mathrm{TiO}_{2}$ Catalyst." Chemosphere 144: 628-34.

[26] Masuda, Y. and Kato, K. 2009. "Synthesis and Phase Transformation of $\mathrm{TiO}_{2}$ Nano-Crystala in Aqueous Solutions." Journal of the Ceramic of Janpan 117: 373-6.

[27] Ranjit, K. T. and Viswanathan, B. 1997. "Synthesis, Characterization and Photocatalytic Properties of Iron-Doped $\mathrm{TiO}_{2}$ Catalysts." Journal of Photochemistry and Photobielogy A: Chemistry 108: 79-84.

[28] Asiltürk, M., Sayllkan, F. and Arpaç, E. 2009. "Effect of $\mathrm{Fe}^{3+}$ Ion Doping to $\mathrm{TiO}_{2}$ on the Photocatalytic Degradation of Malachite Green Dye under UV and VIS-Irradiation." Journal of Photochemistry and Photobiology A: Chemistry 203: 64-71.

[29] Tian, F., Zhang, Y., Zhang, J. and Pan, C. 2012. "Raman Spectroscopy: A New Approach to Measure the 
Percentage of Anatase $\mathrm{TiO}_{2}$ Exposed (001) Facets." J. Phys. Chem. C 116 (3): 7515-9.

[30] Peña-Flores, J. I., Palomec-Garfias, A. F., Márquez-Beltrán, C., Sánchez-Mora, E., Gómez-Barojas, E. and Pérez-Rodríguez, F. 2014. "Fe Effect on the Optical Properties of $\mathrm{TiO}_{2}: \mathrm{Fe}_{2} \mathrm{O}_{3}$ Nanostructured Composites Supported on $\mathrm{SiO}_{2}$ Microsphere Assemblies." Nanoscale Research Letters 9: 1-7.

[31] Reyes-Coronado, D., Rodriguez-Gattorno, G., Espinosa-Pesqueira, M. E., Coss, R. D., Cab, C. and Oskam, G. 2008. "Phase-Pure $\mathrm{TiO}_{2}$ Nanoparticles: Anatase, Brookite and Rutile." Nanotechnology 19: 145605.

[32] Chong, M. N., Lei, S., Jin, B., Saint, C. and Chow, C. W. K. 2009. "Optimisation of an Annular Photoreactor Process for Degradation of Congo Red Using a Newly Synthesized Titania Impregnated Kaolinite Nano-Photocatalyst." Separation and Purification Technology 67: 355-63.

[33] Shirayama, H., Tohezo, Y., and Taguchi, S. 2001. "Photodegradation of Chlorinated Hydrocarbons in the Presence and Absence of Dissolved Oxygen in Water." Water Research 35: 1941-50.

[34] Sánchez, L., Peral, J. and Domènech, X. 1998. “Aniline Degradation by Combined Photocatalysis and Ozonation.” Applied Catalysis B: Environmental 19: 59-65.

[35] Deng, Y. and Zhao, R. 2015. "Advanced Oxidation Processes (AOPs) in Wastewater Treatment." Current Pollution Reports 1: 167-76.

[36] Ma, Y., Zhang, X. T., Guan, Z. S., Cao, Y. A. and Yao, J. N. 2001. "Effects of Zinc(II) and Iron(III) Doping of Titania Films on their Photoreactivity to Decompose Rhodamine B." Journal of Materials Research 16: 2928-33.

[37] Zhou, M., Yu, J. and Cheng, B. 2006. "Effects of Fe-Doping on the Photocatalytic Activity of Mesoporous $\mathrm{TiO}_{2}$ Powders Prepared by an Ultrasonic Method." Journal of Hazardous Materials 137: 1838-47.

[38] Chong, M. N., Jin, B., Chow, C. W. K. and Saint, C. 2010. "Recent Developments in Photocatalytic Water Treatment Technology: A Review." Water Research 44:
2997-3027.

[39] Ochuma, I. J., Fishwick, R. P., Wood, J. and Winterbottom, J. M. 2007. "Optimisation of Degradation Conditions of 1,8-diazabicyclo[5.4.0] undec-7-ene in Water and Reaction Kinetics Analysis Using a Cocurrent Downflow Contactor Photocatalytic Reactor." Applied Catalysis B: Environmental 73: 259-68.

[40] Chin, S. S., Chiang, K. and Fane, A. G. 2006. "The Stability of Polymeric Membranes in a $\mathrm{TiO}_{2}$ Photocatalysis Process." Journal of Membrane Science 275: 202-11.

[41] Toor, A. P., Verma, A., Jotshi, C. K., Bajpai, P. K. and Singh, V. 2006. "Photocatalytic Degradation of Direct Yellow 12 Dye Using UV/TiO 2 in a Shallow Pond Slurry Reactor." Dyes and Pigments 68: 60.

[42] Gogniat, G. T., Thyssen, M., Denis, M., Pulgarin, C. and Dukan, S. 2006. "The Bactericidal Effect of $\mathrm{TiO}_{2}$ Photocatalysis Involves Adsorption onto Catalyst and the Loss of Membrane Integrity.” FEMS Microbiol Lett 258: 18-24.

[43] Rincón, A. G. and Pulgarin, C. 2004. "Effect of PH, Inorganic Ions, Organic Matter and $\mathrm{H}_{2} \mathrm{O}_{2}$ on E. coli K12 Photocatalytic Inactivation by $\mathrm{TiO}_{2}$ : Implications in Solar Water Disinfection.” Applied Catalysis B: Environmental 51: 283-302.

[44] Wang, Y. and Hong, C. S. 1999. "Effect of Hydrogen Peroxide, Periodate and Persulfate on Photocatalysis of 2-chlorobiphenyl in Aqueous $\mathrm{TiO}_{2}$ Suspensions." Water Research 33: 2031-6.

[45] Yu, J. Q. and Matsui, Y. 1997. "Effects of Root Exudates of Cucumber (Cucumis Sativus) and Allelochemicals on Ion Uptake by Cucumber Seedlings." Journal of Chemical Ecology 23: 817-27.

[46] Rao, K. V. S., Subrahmanyam, M. and Boule, P. 2003. "Photocatalytic Transformation of Dyes and by-products in the Presence of Hydrogen Peroxide." Environ. Technol 24(8): 1025-1030.

[47] Tong, T., Zhang, J., Tian, B., Chen, F. and He, D. 2008. "Preparation of $\mathrm{Fe}^{3+}$-Doped $\mathrm{TiO}_{2}$ Catalysts by Controlled Hydrolysis of Titanium Alkoxide and Study on their Photocatalytic Activity for Methyl Orange Degradation." Journal of Hazardous Materials 155: 572-9. 